Article

\title{
Investigating Residents' Attitudes towards Tourism Growth in Downtown Greenville, SC: The Effect of Demographic Variables
}

\author{
Yuting An ${ }^{1, * \mathbb{D}}$, Jang-Won Moon ${ }^{2}$ and William C. Norman ${ }^{3}$ \\ 1 Department of Tourism, Hospitality and Event Management, University of Florida, Gainesville, FL 32611, USA \\ 2 School of Hospitality and Tourism Management, University of South Florida, Sarasota, FL 34243, USA; \\ jangwom@g.clemson.edu \\ 3 Department of Parks, Recreation and Tourism Management, Clemson University, Clemson, SC 29634, USA; \\ wnorman@clemson.edu \\ * Correspondence: yutingan@ufl.edu
}

check for updates

Citation: An, Y.; Moon, J.-W.;

Norman, W.C. Investigating

Residents' Attitudes towards Tourism Growth in Downtown Greenville, SC: The Effect of Demographic Variables. Sustainability 2021, 13, 8474.

https://doi.org/10.3390/su13158474

Academic Editor: Andrea Pérez

Received: 1 July 2021

Accepted: 26 July 2021

Published: 29 July 2021

Publisher's Note: MDPI stays neutral with regard to jurisdictional claims in published maps and institutional affiliations.

Copyright: (C) 2021 by the authors Licensee MDPI, Basel, Switzerland. This article is an open access article distributed under the terms and conditions of the Creative Commons Attribution (CC BY) license (https:/ / creativecommons.org/licenses/by/ $4.0 /)$.

\begin{abstract}
Given the high density of urban spaces, residents and tourists share resources and infrastructure in limited spaces. The purpose of the study is to investigate the influence of residents' perceived tourism impacts on their attitudes towards tourism growth, the effect of proximity to tourism center on residents' attitudes, and how this effect is moderated by residents' demographic features (age, gender, length of residence) in urban settings. A total of 251 responses were collected in downtown Greenville, a tourist zone located in the heart of Greenville, SC, USA. Using multiple regression models and ANOVA, the study suggested that (1) economic impact was the most important predictor of residents' attitudes towards tourism growth, (2) downtown residents were more favorable of tourism growth than county residents, and (3) Age and gender moderated the effect of proximity to a tourism center on residents' attitudes towards tourism growth.
\end{abstract}

Keywords: demographic variables; residents' attitudes; tourism growth; urban spaces; social exchange theory

\section{Introduction}

Tourism growth can bring economic benefit to a local community while negatively influencing its sociocultural and environmental environment $[1,2]$. The concept of sustainable tourism development, introduced into the tourism field, focuses on how to maximize the former while minimizing the impact of the latter [1]. According to McIntyre [3], sustainable tourism is considered an alternative type of tourism, one that enhances the residents quality of life, offers an excellent tourist experience, and balances the quality of the environment on which both parties depend. As a result, communities should consider the sustainable tourism goal of balancing residents' wants and needs, which can result in a strong tourism market orientation [4]. If done properly, sustainable tourism can foster a balanced environment that enhances residents' everyday lives and provides a pleasant travel experience for tourists [5-7].

One salient way to ensure the success of sustainable tourism development is to understand residents' attitudes towards tourism growth [4]. Social exchange theory has been widely accepted and applied in understanding residents' attitudes towards tourism growth. The theory is premised on individuals' evaluations on benefits and costs during resource exchange processes. It is argued that both parties in the exchange process are willing to trade resources if they perceive more benefits than costs. In the field of tourism, the social exchange theory indicates that residents who perceive more benefits than costs are more favorable to tourism development [8]. Such tourism development will potentially benefit the community by generating job opportunities, improving its infrastructure to meet the growth in the number of visitors, increasing the number of parks and recreational facilities, and improving the general standard of living [9-11]. However, tourism can also 
have such negative sociocultural and environmental impacts as an increased cost of living, traffic congestion, and overuse of natural resources [1,12].

The majority of the studies, examining factors influencing residents' attitudes towards tourism development, have been conducted in rural areas in developed countries [13]. However, research regarding residents' attitudes towards tourism growth in urban areas has not received much attention. Urban areas are condensed in nature regarding resources and population. In city areas, tourists and residents share the same infrastructure and leisure facilities in a limited periphery [14]. Residents are more likely to interact with tourists since tourists are looking to experience the everyday life of the residents [15]. As a result, it is important to understand if and how residents living in a tourism center have different attitudes towards tourism growth than residents who live away from a tourism center. [14] One way to explore the potential differences of residents' attitudes towards tourism growth based on the proximity to a tourism center is through analyzing residents' demographic features. Residents' demographic variables (i.e, age, gender, length of residence) indicated the distinct features of resident identities [13,16-18]. Understanding residents' demographic features can help create a satisfactory tourism plan for locals with different identities [18]. Although previous studies have examined the effect of demographic variables on residents' attitudes towards tourism with contradictory results, few studies have considered if residents' demographic features can explain how proximity to a tourism center influences residents' attitudes towards tourism growth.

To summarize, previous studies haven't paid much attention to understanding residents' attitudes towards tourism growth in urban areas. Specifically, the potential differences of residents' attitudes towards tourism development based on their proximity to tourism centers and its driving forces haven't been explored. To explore how proximity to a tourism center affects residents' attitudes towards tourism growth, this study proposes using residents' demographic variables since residents' demographic features indicate their own identities that will influence their behavior and attitudes [19]. To address these research gaps stated above, the purpose of the study is to examine the influence of residents' perceived tourism impacts on their attitudes towards tourism, as well as the effect of proximity to a tourism center on residents' attitudes towards tourism growth in a downtown tourist zone of a popular small urban city. Another goal of this study is to determine how the proximity influences residents' attitudes based on residents' demographic variables. Specifically, this study examines age, gender, and length of residence since these three variables indicate the heterogeneity of a local community [20] that may affect residents' attitudes toward tourism growth.

In this study, three research questions will be answered

1. how do residents' perceived tourism impacts affect their attitudes towards tourism growth?

2. how does proximity to a tourism zone make a difference in residents' attitudes towards tourism growth?

3. how do residents' age, gender, and length of residence moderate the relationship between proximity to a tourism center and their attitudes towards tourism growth?

Downtown Greenville is selected as the research site for the study. It is in the heart of Greenville, which is the fourth tourism city in the State of South Carolina [21]. Downtown Greenville is a revitalized tourism center, which consists of hotels, restaurants, sports venues, parks, and local businesses ventures. The tourism center is a hotspot for travelers to visit, which attracts 2.5 million tourists annually [22]. Both residents and tourists can attend the major local events each season (i.e., Fall for Greenville, Euphoria, and Artisphere), as well as become active users of the convenient facilities and infrastructure in the area [23].

\section{Literature Review}

\subsection{Residents Attitudes towards Tourism Growth and Social Exchange Theory}

According to Eagly and Chaiken [24], attitude is a psychological term, reflecting an individual's assessment of certain objects as being seen as having or not having favors. 
According to Zhang et al. [25], residents' attitudes towards tourism growth indicate how they expect tourism development to be coordinated to achieve its sustainability. Specifically, residents' attitudes are based on four factors: long-term planning, a tourism-centered economy, community participation, and assurance of tourist satisfaction. These four factors emphasized residents' extensive involvement and administrative role in the process of tourism planning, both of which are key for a successful sustainable tourism industry.

One of the well-known theories to understand residents' attitudes towards tourism growth is the social exchange theory. Social exchange theory emphasizes the interaction among people [26]. The essence of the social exchange theory is concerned with the assessment of the benefits and the costs to both parties [27], two factors leading to their willingness to participate in the process of trading various kinds of rewards [28-31]. The goal of participation in this trading process is to optimize the balance between the benefits and the expenses and to obtain mutual profits for both parties [31,32]. It was argued that the participants are likely to continue interacting if they see more benefits and discontinue the relationship if they see more costs [29]. In the field of tourism, Ap [28] applied the social exchange theory to explain how residents perceived tourism development, arguing that residents who assessed more benefits than expenses have more willingness to participate in the trading process as they are more positive on tourism growth [9]. Social exchange theory is suitable to understand residents' attitudes of tourism development since the optimal consequence of the trading process is the gratification for both tourists and residents [32,33], an intangible form of interaction during the trading process [34], which will eventually reach the goals of sustainable tourism development [4]. Using the social exchange theory and the definition of residents' attitudes towards tourism growth, proposed by Zhang et al. [25], not only satisfies the premises of sustainable tourism growth but also addresses the importance of residents' participation in tourism planning.

\subsection{Tourism Impacts}

\subsubsection{Economic Impacts}

Extending the assumptions of the social exchange theory, residents' attitudes towards tourism growth are influenced by residents' perceptions of tourism growth [8], which are categorized into economic, sociocultural, and environmental dimensions [35]. Tourism has significantly contributed to the economic growth in many regions [36]. Specifically, in rural and developing areas, tourism has become the main source of economic development since traditional industries have declined [37]. Previous research has suggested that residents ${ }^{\prime}$ perceived economic impacts were one of the most influential factors to predict residents ${ }^{\prime}$ attitudes towards tourism development [38]. These perceived tourism impacts were sorted into positive and negative dimensions. The positive categories include increased job opportunities, salary growth, improved infrastructure, and enhanced living standards [7,9,39-41]. The negative category mainly focuses on the increased cost of living [40].

Most of the previous studies have determined that residents' perceived tourism impacts affected residents' attitudes towards tourism growth. Specifically, positive perceived economic impacts were the most influential factor for residents' attitudes towards tourism growth [8,42-44]. On the other side, a study found out that both positive economic impacts and negative economic impacts significantly predicted residents' attitudes towards tourism growth. Relative to negative economic impacts, positive economic impacts were more important in affecting residents' attitudes toward tourism development [40]. Consistent with previous studies, this study proposes that

Hypothesis 1a (H1a). Residents' perceived economic impacts will significantly influence their attitudes towards tourism growth.

\subsubsection{Sociocultural Impacts}

In addition to economic benefits and costs, tourism growth also causes both sociocultural benefits and costs to the community. Sociocultural impacts are concerned with the 
routine life, cultural values, and changes in conventions resulting from tourism growth [45]. Tourism growth has been found to stimulate connections between tourists and the local community, a situation with both positive and negative impacts [38]. On the positive side, these interactions strengthen cultural exchange, increase the number of recreational and leisure facilities and activities, facilitate the conservation of historical and heritage sites, and help maintain the original culture of the local community $[9,46,47]$. On the negative side, tourism increases the crime rate and results in traffic congestion as well as changes or, in some cases the loss, of the original culture of the community [42,48].

Previous studies have examined the relationship between residents' perceived sociocultural impacts and their attitudes towards tourism growth. Although a small number of previous studies have determined the nonsignificant relationship between perceived sociocultural impacts and their attitudes towards tourism growth [49], most studies have found out that perceived sociocultural impacts have significantly predicted their attitudes towards tourism development $[8,43,46,50]$. Specifically, compared with other tourism influences, sociocultural impacts were a moderately influential factor of residents' attitudes [8,46]. According to Meimand et al. [49], compared to negative sociocultural impacts, positive sociocultural impacts were more influential in predicting residents' attitudes towards tourism development. Based on the assumptions of social exchange theory, this study proposes

Hypothesis $\mathbf{1 b} \mathbf{( H 1 b ) . ~ R e s i d e n t s ' ~ p e r c e i v e d ~ s o c i o c u l t u r a l ~ i m p a c t s ~ w i l l ~ s i g n i f i c a n t l y ~ i n f l u e n c e ~ t h e i r ~}$ attitudes towards tourism growth.

\subsection{Environmental Impacts}

Environmental influence is considered an important element for tourism researchers to understand how residents perceive tourism growth since the environment is one of the primary driving forces attracting tourists [36]. Similar to perceived economic and sociocultural impacts, residents perceive environmental impacts both positively and negatively. However, more negative environmental impacts have been identified than positive. Specifically, residents perceive that tourism development leads to air pollution, increased trash, environmental deterioration, noise, and congestion [9,51-53]. On the other hand, locals perceive that tourism growth can stimulate their efforts to conserve their natural environment and engage in sustainable tourism [9,52].

Past studies have investigated the relationship between residents' perceived environmental impacts and their attitudes towards tourism growth. However, different results were obtained. Some studies have determined that perceived environmental impacts didn't predict residents' attitudes towards tourism growth [54]. On the contrary, other studies have found out that environmental impacts influence residents' attitudes towards tourism development. A study determined that residents complained about the negative environmental impacts, which led to negative attitudes towards tourism development [51]. Nevertheless, several studies have suggested that residents' perceived environmental impacts positively affected their attitudes towards tourism growth $[8,49,55]$. As a result, in line with the assumptions of the social exchange theory, this study proposes that

Hypothesis 1c (H1c). Residents' perceptions of environmental impacts will significantly affect their attitudes towards tourism growth.

\subsection{Proximity to a Tourist Center}

The concept of proximity involves several perspectives. Some studies measured proximity from the perspective of geographical distance, while others measured it from the perspectives of social and psychological distance [56]. The proximity to a tourist center means residents' geographical distance to this zone. It is important in urban tourism due to the dense and diversified nature of urban cities [14] as both residents and tourists share the same urban infrastructure in a limited space [57]. Several researchers have explored how 
the proximity to a tourist center affected residents' attitudes towards tourism growth. They examined the effect through the associated residents' perceived tourism impacts. However, the results of such studies varied.

According to Liu and $\mathrm{Li}$ [17] maintained that residents living away from the tourist zone in India were more supportive of tourism growth due to its increased job opportunities and better access to recreational facilities. Similarly, residents living near the tourist zone were less favorable to tourism growth because of its increased living expenses. These results were supported by Rasoolimanesh et al.'s [58] study conducted on heritage sites in Iran. The reason for these results could be that residents who are proximal to tourist zones have higher chances of interacting with tourists in these areas [59]. However, a study conducted by Weaver and Lawton [60] found that the proximity to a tourist zone did not explain residents' attitudes towards tourism growth caused by tourism.

Unlike previous studies regarding proximity to a tourist center as a dichotomous variable, this study categorizes the variable into three groups due to the nature of urban spaces. Specifically, this study compares the differences among attitudes of downtown residents, city residents and county residents (County residents represent residents who live outside the City of Greenville but within the County) on tourism development. As a result, this study proposes that

Hypothesis 2 (H2). Downtown residents hold different attitudes towards tourism growth from city and county residents.

\subsection{Residents' Demographic Variables}

As mentioned in the previous section, past studies have attempted to examine how proximity to a tourism center affects residents' attitudes towards tourism growth via residents' perceived tourism impacts. However, the results were disparate. An alternative way to explore this effect is through examining residents' demographic variables. Residents' demographic variables can be the explanation regarding the effect of proximity on residents' attitudes towards tourism growth since a person's identity shapes his or her attitudes and values of society [19]. In this study, residents' age, gender, and length of residence are used since they indicate the heterogeneity of the local community [20], which might affect residents' attitudes towards tourism growth.

\subsubsection{Age}

Previous studies have shown mixed results regarding the effect of age on residents' attitudes towards tourism development [61]. Such studies explained the results by addressing the association of age and perceived tourism impacts, which results in significant or non-significant changes in residents' attitudes towards tourism growth. On one side, older adults are more favorable towards tourism growth since they tend to perceive that they receive more economic benefits $[62,63]$ and concern less on the environmental impacts [64]. The underlying reasoning is that older residents are more likely to obtain managerial roles and have the funds in tourism businesses. According to adults' lifespan patterns, middle-aged adults earn higher income and obtain higher positions and managerial roles in workplaces [65]. On the other side, Sinclair-Maragh [18] determined that younger residents were more favorable towards tourism development. Tourism development increases job openings in tourism businesses (i.e., restaurants, hotels). Such openings are mostly filled by younger generations, which leads to younger residents' positive attitudes towards tourism growth.

In general, differences of residents' attitudes towards tourism growth in varying age groups are associated with increased income and job opportunities. Similarly, this reasoning is suitable for explaining the effect of proximity to a tourism center on residents' attitudes towards tourism growth since residents who are proximal to a tourism center have easy access to the economic benefits [66]. As a result, this study proposes that 
Hypothesis 3a (H3a). Age will moderate the relationship between proximity to a tourism center and residents' attitudes towards tourism growth.

\subsubsection{Gender}

Prior studies have received varied results regarding the effect of gender on residents' attitudes towards tourism growth. Such studies have explained the effect deriving from the links between gender and its associated tourism influences. On one hand, past studies have indicated that female residents were less favorable towards tourism growth $[13,67,68]$ since they tend to be more sensitive and show more concern about issues arising in the community [69]. Another rationale originates from income inequality between males and females, suggesting that females receive less economic benefits and have less positive attitudes towards tourism growth [67]. On the contrary, other studies have determined that females showed more positive attitudes towards tourism growth because of the job openings deriving from tourism growth allow more female residents to earn second income (i.e., housekeeping), especially in the developing countries [18,70]. However, other studies haven't found out the influence of gender on residents' attitudes towards tourism growth [71,72].

As a result, the gender differences in residents' attitudes towards tourism growth derive from the essential divergent roles that males and females are having in society. While males' traditional roles focus on supporting their families with their income [73], females are more sensitive to community changes and development [74]. In a tourism center where gathers people and compatible infrastructure and facilities in a limited area, gender might explain the effect of proximity to a tourism center on residents' attitudes towards tourism growth because more business opportunities are arising. Residents living near a tourism center are more or less sensitive to these opportunities depending on their gender identities. Hence, this study proposes that

Hypothesis $\mathbf{3 b} \mathbf{b} \mathbf{H} \mathbf{3} \mathbf{b})$. Gender will moderate the relationship between proximity to a tourism center and residents' attitudes towards tourism growth.

\subsubsection{Length of Residence}

Past studies have explored to gain knowledge in residents' length of residence and their attitudes towards tourism development. However, the results varied. On one side, long-term residents were less favorable towards tourism growth since they witness unexpected community changes [75]. On the other side, long-term residents were more supportive of tourism development because they are emotionally attached to their communities [76], driving them to focus more on the positive sides of tourism development, such as economic gains [17]. Nevertheless, other studies have found out that length of residence didn't influence residents' attitudes towards tourism growth $[18,77,78]$.

Overall, there are two main reasons in explaining the effect of length of residence on residents' attitudes towards tourism growth: individual's belongingness to the community and the community changes. Length of residence might serve as an indicator, regarding the effect of proximity to a tourism center, on residents' attitudes towards growth because residents define their community based on where they live. Additionally, a tourism center might experience more changes and transitions than other places in a destination because of the built infrastructure and facilities to meet tourists' needs. As a result, this study proposes that

Hypothesis $3 \mathbf{c}(\mathbf{H} 3 \mathbf{c})$. Length of residence will moderate the relationship between proximity to a tourism center and residents' attitudes towards tourism growth. 


\section{Method}

\subsection{Study Site}

The data was collected in downtown Greenville. Greenville, South Carolina, the largest city in Greenville County and the Update region, is located in northwestern South Carolina [79] ("Greenville", n.d.). Downtown Greenville, the heart of the city, is both a tourist zone and a residential area where parks, sports venues, restaurants, and hotels are located. It is a place where both residents and tourists share the same infrastructure. Greenville's city center has been recognized as one of the best downtowns in America by Livability [80] and one of the top cities to visit by Expedia [81]. There were 5 million tourists visiting the city of Greenville in 2019 , contributing $\$ 1.3$ billion in expenditures and 74.3 million in taxation to the community [82].

\subsection{Survey Instrument}

The SUS-TAS scale was developed by Choi and Sirakaya [36] to measure residents' attitudes towards sustainable tourism development. The scale reflects a new sustainable tourism development paradigm to bring the success of sustainable tourism development. To increase residents' participation and controls during the tourism development planning process, the scale intends to provide detailed information regarding residents' perceptions of tourism impacts and their attitudes towards sustainable tourism development. The original scale comprises 44 items in 7 main dimensions: social expenses, economic benefits, environmental sustainability, long-term planning, tourism-centered economy, community participation, and tourist satisfaction assurance. Using their original 44-item scale [36], researchers validated and reduced the items in different contexts [25,83].

This study adopted the SUS-TAS scale consisting of 20 statements validated by Zhang et al. [25] The first section of the questionnaire comprises 9 items regarding tourism impacts, with 3 statements for each of the three impacts, economic, sociocultural, and environmental. The second section focuses on residents' attitudes towards tourism development, with a total number of 11 statements measuring the four dimensions of long-term planning, tourism-centered economy, community participation and tourist satisfaction assurance. The last section of the survey examines respondents' demographic information, including age, gender, education level, race and ethnicity, annual income, zip code of residence, and length of residence. This study used age, gender, length of residence, and zip code to test the hypotheses.

\subsection{Validity Check and Data Collection}

Prior to data collection, a group of experts was invited to review survey items to check the validity of the survey instrument. The group was composed of two tourism professors, one leisure professor and one statistics professor. Based on their comments and suggestions, two survey items were revised. A pilot study was conducted to check the readability and reliability of survey items. According to the 32 responses received from the pilot study, survey items were reworded and revised. Based on the results of expert reviews and the pilot study, data were collected in downtown Greenville using a self-administered survey method. To ensure potential participants' eligibility to take part in the survey, the researchers approached a person/people passing by and screened them by asking them if they resided in Greenville County. The researchers then gave a questionnaire to the qualified respondents who were willing to complete it. Overall, data were collected from 11 locations in downtown Greenville for 11 days. Among the 320 people approached, a total of 251 respondents completed the questionnaire for a response rate of $85.1 \%$.

\section{Results}

\subsection{Respondent Profile}

Of the 251 respondents in the study, male respondents $(N=147,58.6 \%)$ and female respondents $(N=104,41.4 \%)$ were distributed (Table 1$)$. For the majority of respondents, the age ranged from $18-25(33.9 \%)$ and $26-30(26.7 \%)$. As for residence, $45.6 \%$ of the sample 
were city residents, followed by county residents (31.6\%) and downtown residents $(22.8 \%)$. For the length of residence, the majority of respondents have resided in Greenville County for less than 10 years: $36.8 \%$ between $1-5$ years, $16.4 \%$ less than 1 year $(16.4 \%)$ and $14.8 \%$ between $5-10$ years $(14.8 \%)$. In addition, the largest two groups of downtown residents have lived there $1-5$ years $(N=33)$ and less than one year $(N=11)$. Similarly, more city residents in this study have lived in the area for less than 5 years $(N=58)$. For county residents, a larger percentage of people have lived in the county for $1-5$ years $(N=20)$ and $16-20$ years $(N=15)$.

Table 1. Descriptive Statistics.

\begin{tabular}{|c|c|c|c|c|}
\hline Demographic Variables & \multicolumn{3}{|c|}{$N=251$} & \multirow[t]{2}{*}{$\%$} \\
\hline Gender & & & & \\
\hline Male & & 147 & & 58.6 \\
\hline Female & & 104 & & 41.4 \\
\hline \multicolumn{5}{|l|}{ Age $(M=34, S D=14.03)$} \\
\hline Under 18 & & 8 & & 3.2 \\
\hline $18-25$ & & 85 & & 33.9 \\
\hline $26-35$ & & 67 & & 26.7 \\
\hline $36-45$ & & 35 & & 13.9 \\
\hline $45-55$ & & 31 & & 12.4 \\
\hline Above 55 & & 25 & & 10 \\
\hline \multicolumn{5}{|l|}{ Residence } \\
\hline Downtown & & 57 & & 22.8 \\
\hline City & & 114 & & 45.6 \\
\hline County & & 79 & & 31.6 \\
\hline Length of Residence $(M=9.46, S D=11.13)$ & Downtown & City & County & \\
\hline Less than 1 year & 11 & 21 & 9 & 16.4 \\
\hline $1-5$ years & 33 & 37 & 20 & 36.4 \\
\hline $6-10$ years & 5 & 20 & 12 & 14.8 \\
\hline $11-15$ years & 2 & 8 & 6 & 6.4 \\
\hline $16-20$ years & 4 & 10 & 15 & 11.6 \\
\hline 21-24 years & 0 & 12 & 8 & 8.0 \\
\hline More than 25 years & 2 & 6 & 8 & 6.4 \\
\hline
\end{tabular}

\subsection{Reliability Test and Descriptive Statistics}

A reliability test was conducted to examine if the items were compatible with each other regarding economic impacts, sociocultural impacts, environmental impacts and residents' attitudes towards tourism growth. As seen in Table 2, the scales for economic impacts, sociocultural impacts and environmental impacts exhibited acceptable reliability as their Cronbach alphas were $0.78,0.75$, and 0.70 , respectively. However, the reliability score for residents' attitudes towards tourism growth was relatively low (Cronbach's alpha $=0.6)$. After deleting the item "tourism businesses should measure visitor satisfaction," the reliability of the scale improved to an acceptable level (Cronbach's alpha $=0.80)$. In addition, according to in Table 2, the respondents in this study perceived economic $(M=4.29, S D=0.69)$, sociocultural $(M=4.19, S D=0.72)$, and environmental impacts $(M=3.49, S D=0.74)$ positively and showed favorable attitudes towards tourism growth $(M=4.06, S D=0.48)$. 
Table 2. Reliability and Descriptive Statistics.

\begin{tabular}{|c|c|c|c|}
\hline Variables & Statement ${ }^{1}$ & $M$ & $S D$ \\
\hline \multirow{3}{*}{$\begin{array}{c}\text { Economic Impact } \\
(M=4.29) \\
(S D=0.69) \\
(\text { Cronbach's alpha }=0.78)\end{array}$} & Tourism is good for our community's economy. & 4.36 & 0.83 \\
\hline & Tourism creates new markets for local products. & 4.35 & 0.72 \\
\hline & $\begin{array}{l}\text { Tourism benefits businesses other than just the } \\
\text { tourism industry in our community. }\end{array}$ & 4.15 & 0.91 \\
\hline \multirow{3}{*}{$\begin{array}{l}\text { Sociocultural Impact } \\
\quad(M=4.19) \\
(S D=0.72) \\
(\text { Cronbach's alpha }=0.75)\end{array}$} & $\begin{array}{l}\text { My community is not overcrowded because of the } \\
\text { tourism industry. }\end{array}$ & 3.98 & 0.89 \\
\hline & $\begin{array}{l}\text { My quality of life is not destroyed because of tourism } \\
\text { in downtown Greenville. }\end{array}$ & 4.43 & 0.83 \\
\hline & $\begin{array}{l}\text { Tourists in my community do not disrupt my quality } \\
\text { of life. }\end{array}$ & 4.16 & 0.91 \\
\hline \multirow{3}{*}{$\begin{array}{l}\text { Environmental Impact } \\
\qquad(M=3.49) \\
(S D=0.74) \\
(\text { Cronbach's alpha }=0.70)\end{array}$} & $\begin{array}{l}\text { The natural environment in our community is } \\
\text { protected by the tourism industry now and for the } \\
\text { future. }\end{array}$ & 3.20 & 0.84 \\
\hline & $\begin{array}{l}\text { Tourism improves the environment in our } \\
\text { community. }\end{array}$ & 3.71 & 1.03 \\
\hline & $\begin{array}{l}\text { Tourism development in our community promotes } \\
\text { positive environmental ethics. }\end{array}$ & 3.57 & 0.95 \\
\hline \multirow{10}{*}{$\begin{array}{l}\text { Residents' Attitudes } \\
\text { towards Tourism Growth } \\
\qquad(M=4.06) \\
(S D=0.48) \\
(\text { Cronbach Alpha }=0.80)\end{array}$} & $\begin{array}{l}\text { Successful tourism development needs advanced } \\
\text { tourism planning. }\end{array}$ & 4.05 & 0.79 \\
\hline & $\begin{array}{l}\text { Tourism development needs well-coordinated } \\
\text { planning. }\end{array}$ & 4.21 & 0.67 \\
\hline & $\begin{array}{l}\text { We cannot be short-sighted when planning for } \\
\text { tourism development. }\end{array}$ & 4.27 & 0.69 \\
\hline & $\begin{array}{l}\text { Local residents should receive a fair share of } \\
\text { economic benefits from tourism. }\end{array}$ & 3.68 & 0.93 \\
\hline & $\begin{array}{l}\text { The tourism industry should contribute economically } \\
\text { to the community's improvement. }\end{array}$ & 4.34 & 0.65 \\
\hline & $\begin{array}{l}\text { The tourism industry should try to purchase goods } \\
\text { and services within the community. }\end{array}$ & 4.40 & 0.68 \\
\hline & $\begin{array}{l}\text { The tourism industry should ensure a high-quality } \\
\text { tourist experience. }\end{array}$ & 4.24 & 0.57 \\
\hline & $\begin{array}{l}\text { Community attractiveness is a core element of } \\
\text { ecological "appeal" for visitors. }\end{array}$ & 4.26 & 0.67 \\
\hline & $\begin{array}{l}\text { Tourism decisions should be made by all members in } \\
\text { the community regardless of their backgrounds. }\end{array}$ & 3.64 & 1.07 \\
\hline & $\begin{array}{l}\text { Everyone in the community should participate in the } \\
\text { decision-making process for tourism development. }\end{array}$ & 3.49 & 1.09 \\
\hline
\end{tabular}

${ }^{1}$ Based on a scale of $1=$ strongly disagree and $5=$ strongly agree.

\subsection{Effect of Tourism Influence}

The average of economic impacts, sociocultural impacts, environmental impacts, and residents' attitudes towards tourism growth was calculated to represent the corresponding variables. Before running regression analyses, preliminary analyses were conducted. The data were normally distributed. In addition, there were no multicollinearity problems. Seven cases were removed because of detected multivariate outliers based on their Mahalanobis distance.

To test the effect of economic, sociocultural and environmental impacts on residents' attitudes towards tourism growth, a multiple regression was conducted where the dependent variable was residents' attitudes towards tourism growth and the independent 
variables were economic impacts, sociocultural impacts and environmental impacts. The independent variables explained $54 \%$ of the variances, $F(3,239)=57.90, R^{2}=0.54$, and $p<0.001$. Seen in Table 3, economic impact predicted residents' attitudes towards tourism growth $(\beta=0.63, t(239)=7.51, p<0.001)$ significantly. Sociocultural impact $(\beta=0.30$, $t(239)=5.00, p<0.001)$ and environmental impact $(\beta=0.11, t(239)=2.21, p=0.03)$ were significant predictors. Among these three tourism impacts, the economic impact was the more important factor in predicting residents' attitudes towards tourism growth. Thus, Hypothesis 1a-c, were all supported.

Table 3. Multiple Regression between Tourism Impacts and Attitudes to Tourism Growth.

\begin{tabular}{|c|c|c|c|c|}
\hline \multirow[b]{2}{*}{ Variables } & \multicolumn{4}{|c|}{ Coefficient } \\
\hline & $B$ & $\beta$ & $t$ & $p$ \\
\hline Economic Impact & 0.70 & 0.63 & 7.51 & $0.00 * * *$ \\
\hline Sociocultural Impact & 0.30 & 0.30 & 5.00 & $0.00 * * *$ \\
\hline Environmental Impact & 0.27 & 0.11 & 2.21 & $0.03 *$ \\
\hline$R^{2}$ & \multicolumn{4}{|c|}{0.54} \\
\hline $\mathrm{F}$ & \multicolumn{4}{|c|}{57.90} \\
\hline$p$ & \multicolumn{4}{|c|}{$0.00^{* * *}$} \\
\hline
\end{tabular}

\subsection{Effect of Proximity to Tourist Zone}

Before testing $\mathrm{H} 2$, the variable proximity to tourist zone was created based on respondents' self-reported zip codes. Respondents with zip code 29601 were coded as 1 and categorized as downtown residents, while those with zip codes ranging from 29602 to 29617 were coded as 2 and sorted as city residents. The remaining respondents were coded as 3 and considered as county residents. For the county residents, the researchers checked each zip code to confirm that each reflected a city in Greenville County. Before determining the effect of proximity to a tourist zone, preliminary analyses were conducted, the results indicating that the datapoints were normally distributed, and the assumptions of homogeneity variances were satisfied.

To test H2, a one-way ANOVA was conducted with proximity to a tourist zone as the independent variable and residents' attitudes towards tourism growth as the dependent variable. According to Table 4, the results indicated that the one-way ANOVA was statistically significant, $F(2,248)=3.72, p=0.03$. Post-hoc comparisons using Tukey revealed that downtown residents $(M=4.19, S D=0.46)$ were more favorable towards tourism growth than the county residents $(M=3.97, S D=0.47 ; p=0.02)$. Therefore, Hypothesis 2 was supported.

Table 4. Effect of Proximity to a Tourism Center.

\begin{tabular}{|c|c|c|c|c|c|c|c|c|}
\hline \multirow{3}{*}{ Variables } & \multicolumn{6}{|c|}{ Proximity to a Tourism Center } & \multirow{3}{*}{$F$} & \multirow{3}{*}{$p$} \\
\hline & \multicolumn{2}{|c|}{ Downtown } & \multicolumn{2}{|c|}{ City } & \multicolumn{2}{|c|}{ County } & & \\
\hline & $M$ & $S D$ & $M$ & $S D$ & $M$ & $S D$ & & \\
\hline Attitudes towards Tourism Growth & $4.19 *$ & 0.46 & 4.06 & 0.48 & $3.97 *$ & 0.47 & 3.72 & $0.03 *$ \\
\hline
\end{tabular}

\subsection{Moderation Effect of Age}

Before testing the moderation effect of age on proximity to a tourist center and residents' attitudes towards tourism growth, preliminary analyses were conducted. The results of the preliminary analyses indicated that data was normally distributed without any missing values and outliers. A factorial ANOVA analysis was conducted to test the interaction effect of age proposed in Hypothesis 3a. The interaction effect of age and proximity to a tourist center was statistically significant $F(8,236)=1.91, p=0.04$. 
A post hoc test using Tukey LSD was conducted to explore the specific differences. According to Table 5, for downtown residents, residents who are in age group 40-50 $(M=4.7, S D=0.42)$ were more favorable towards tourism growth than whom were in the age group of 18-29 $(M=4.16, S D=0.48, p=0.03), 30-39(M=4.13, S D=0.54, p=0.02)$, and above $50(M=4.12, S D=0.39, p=0.04)$. For city residents, residents who were in the age group of $40-50(M=4.32, S D=0.35)$ showed more positive attitudes towards tourism growth than whom are in the age group of $14-17(M=3.45, S D=0.07, p=0.01), 18-29$ $(M=4.02, S D=0.45, p=0.02)$, and $30-39(M=3.84, S D=0.52, p=0.003)$. Residents who were above $50(M=4.16, S D=0.50)$ were more in favor of tourism development than whom were in the age group of 14-17 $(M=3.45, S D=0.07, p=0.04)$, and 30-39 $(M=3.84$, $S D=52, p=0.03)$. Therefore, Hypothesis 3a was supported.

Table 5. Moderation Effect of Age.

\begin{tabular}{|c|c|c|c|c|c|c|}
\hline \multirow{2}{*}{ Proximity to a Tourism Center } & \multicolumn{4}{|c|}{ Age Group Comparison } & \multirow{2}{*}{$F$} & \multirow{2}{*}{$p$} \\
\hline & Age Group & $M$ & Age Group & $M$ & & \\
\hline \multirow{4}{*}{ Downtown } & \multirow{4}{*}{$40-50$} & \multirow{4}{*}{4.7} & $0-17$ & 4.45 & \multirow{13}{*}{1.91} & \multirow{13}{*}{0.04 * } \\
\hline & & & $18-29$ & $4.16^{*}$ & & \\
\hline & & & 30-39 & $4.13 *$ & & \\
\hline & & & Above 50 & $4.12 *$ & & \\
\hline \multirow{5}{*}{ City } & \multirow{3}{*}{$40-50$} & \multirow{3}{*}{4.32} & $14-17$ & $3.45 *$ & & \\
\hline & & & $18-29$ & $4.02 *$ & & \\
\hline & & & $30-39$ & $3.84^{* *}$ & & \\
\hline & \multirow{2}{*}{ Above 50} & \multirow{2}{*}{4.16} & $14-17$ & $3.45 *$ & & \\
\hline & & & $30-39$ & $3.84 *$ & & \\
\hline \multirow{4}{*}{ County } & \multirow{4}{*}{$40-50$} & \multirow{4}{*}{4.06} & $0-17$ & 3.98 & & \\
\hline & & & $18-29$ & 4.00 & & \\
\hline & & & $30-39$ & 3.93 & & \\
\hline & & & Above 50 & 3.80 & & \\
\hline
\end{tabular}

\subsection{The Moderation Effect of Gender}

To determine Hypothesis $3 b$, a factorial ANOVA was used. As seen in Table 6, the interaction effect of gender and proximity to tourism center was statistically significant, $F(2,243)=5.07, p<0.001$. To determine the specific differences, a post hoc test using Tukey was run. According to the results, for city residents, female residents $(M=4.18, S D=0.44)$ were more positive towards tourism growth than male residents $(M=3.94, S D=0.49)$ since $p=0.01$ Also, for downtown residents, male residents $(M=4.28, S D=0.44)$ were more favorable towards tourism development than female residents $(M=4.03, S D=0.46)$ due to the significant $p=0.04$. However, for county residents, female residents $(M=3.94$, $S D=0.52$ ) didn't have significantly different attitudes towards tourism growth than male residents $(M=4.02, S D=0.40)$ because of its $p=0.40$. Hence, Hypothesis $3 \mathrm{~b}$ was supported.

Table 6. The Interaction Effect of Gender.

\begin{tabular}{cccc}
\hline \multirow{2}{*}{ Proximity to a Tourism Center } & \multicolumn{2}{c}{ Gender } & $\boldsymbol{p}$ \\
\cline { 2 - 3 } & Male & Female \\
\hline Downtown & $4.28^{*}$ & $4.03^{*}$ & $0.00^{*}$ \\
City & $3.94^{*}$ & $4.18^{*}$ & 3.94 \\
\hline County & 4.02 & 34 \\
\hline
\end{tabular}

${ }^{*} p<0.05$.

\subsection{The Moderation Effect of Length of Residence}

Before testing $\mathrm{H} 5$, a preliminary analysis was conducted. The results of the preliminary analysis indicated that the data were normally distributed without any missing values and 
outliers. To test the moderation effect of length of residence, a factorial ANOVA analysis was conducted. Based on the results, the interaction effect of age was not significant, $F(2,245)=1.46, p=0.23$. Therefore, Hypothesis $3 c$ was not supported.

\section{Discussion}

The purpose of this study was to explore the influences of residents' perceived tourism impacts on their attitudes towards tourism development, as well as the effect of proximity to a tourism center on residents' attitudes towards tourism growth in an urban setting. Moreover, the study was to determine how residents' demographic variables (age, gender, length of residence) can influence the effect of proximity to a tourism center on their attitudes. The results showed that participants in this study viewed tourism influences positively and had favorable attitudes toward tourism development. This study also found that economic impact was the most important significant predictor of residents' attitudes towards tourism growth among these three significant tourism impacts. Regarding residents ${ }^{\prime}$ proximity to a tourism center, downtown residents were more favorable towards tourism growth than county residents. In terms of the moderation effects of residents' demographic variables, both age and gender significantly moderated the effect of proximity to a tourism center on residents' attitudes towards tourism growth, while the length of residence didn't show any significant moderation effects.

\subsection{Tourism Impacts}

The results from this study indicated that economic impact was the most important predictor of residents' attitudes towards tourism growth among all of the three tourism impacts (economic, sociocultural, and environmental impacts). These results were partially consistent with previous studies arguing that both positive and negative tourism impacts significantly affected residents' attitudes towards tourism growth $[4,48,84]$. In these three studies, the positive tourism impacts were primarily economic ones, and the negative impacts were primarily sociocultural and environmental. One reason could be that residents in Greenville view tourism growth as a way to strengthen the economy [85]. Hence, compared to other sociocultural and environmental impacts, these benefits were much more important, resulting in their favorable attitudes towards tourism growth [53]. Another reason could be that the tourism growth in Greenville is still in the involvement phase as described by Butler's [86] tourism life cycle model. In this stage, the local community begins building infrastructure and offering services to tourists. This might explain why residents in this study valued the economic impact the most because locals realized an economic benefit from the tourism facilities being built (i.e., restaurants and hotels) through the creation of local job opportunities and the increase in the cash flow for the business owners who opened and operated such facilities.

\subsection{Proximity to a Tourist Center}

This study determined that there were significant differences in resident attitudes towards tourism growth based on proximity to a tourist zone. Specifically, in this study, downtown residents were more favorable towards tourism growth than county residents. These results were consistent with the findings from Juroski and Gursoy [59], suggesting that environmentally responsible residents living near a natural recreation area are more supportive of tourism growth than those who live away from that area. For this study, downtown residents were more favorable to tourism growth than the county residents because the former more directly experienced the benefits from the economic gains and employment opportunities that the tourist zone and surrounding infrastructure provided as well as the availability of leisure and recreation resources [66]. The downtown residents realized the economic advantages and the convenience that tourism infrastructure brought because of their geographical advantage. 


\subsection{Moderation Effect of Age}

Based on the results from this study, age moderated the effect of proximity to a tourism center on residents' attitudes towards tourism growth. Specifically, for downtown residents, middle-aged residents were more favorable towards tourism growth than other age groups. Similarly, for people living in the city, middle-aged and older residents were more favorable comparing to younger residents. The results can be explained that middle-aged and older residents paid more attention to the accessibility of infrastructure [87], which is maximized in the downtown tourism center area due to its compact nature. Moreover, middle-aged residents reached the highest status and income in their career development during their entire life courses [88]. Hence, middle-aged residents were more sensitive to economic benefits, which led to the most favorable attitudes towards tourism growth among all the age groups.

\subsection{Moderation Effect of Gender}

The results of the study indicated that gender moderated the effect of proximity to a tourism center on residents' attitudes towards tourism growth. In the downtown area, male residents were more favorable towards tourism development. In the city area, female residents were more positive towards tourism growth. Downtown tourism center brings a large portion of economic benefits to the area. Due to the income differences between males and females, female residents receive less economic blooming from tourism development, which led to less favorable attitudes towards tourism growth than male residents. Since the traditional role of males focuses more on earning income and supporting their families [73], they are more sensitive to the economic gains from tourism development in the downtown area, which resulted in their more positive attitudes towards tourism development. Traditionally, female roles focus more on taking care of their families and concentrating on community building and development [74]. In this study, females living in the city area were concerned less about the negative community changes since the city area is away from the downtown tourism area, which raises some safety concerns and causes negative community changes. As a result, females living in the city were more supportive of tourism growth.

\subsection{Moderation Effect of Length of Residence}

Nevertheless, length of residence didn't have a significant moderation effect on the relationship between proximity to a tourism center and residents' attitudes towards tourism growth. The results were partially consistent, arguing that long-term residents and shortterm residents showed similar attitudes towards tourism growth [18]. The reason is that tourism has been rapidly developed in the last 10 years in Greenville. More than $50 \%$ of the residents have lived in Greenville for less than 10 years. The emotional attachment to their community suggested by previous studies [76] hasn't been fully developed since the length of residence is not sufficient. Greenville tourism is still in the involvement stage where an increasing number of tourism facilities have been constructed to match tourist inflow expansion. In this phase, residents haven't generated any negative attitudes towards tourism growth $[86,89]$. As a result, long-term residents in Greenville haven't lived long enough in their communities to witness any negative community changes, which explained that long-term residents and short-term residents were both favorable towards tourism growth regardless of where they live.

\subsection{Implications}

This study provided new knowledge in understanding residents' attitudes towards tourism growth in urban settings. The study investigated the influence of proximity to a tourism center on residents' attitudes towards tourism growth. It validated the nature of urban spaces where both urban residents and visitors share the same resources and infrastructure [14], leading to the differences in residents' attitudes towards tourism growth. This study also examined the moderation effect of residents' demographic variables on 
proximity to a tourism center and residents' attitudes towards tourism growth, which hasn't been tested in previous studies. The moderation effects of residents' demographic variables explained how the proximity to a tourism center influences residents' attitudes towards tourism growth. Moreover, the moderation effects validated that individual's identity influences their attitudes and values [19]. The significant results of the moderation effects indicated that residents' demographic features are distinct, which affected residents living in different proximity to a tourism center had varying attitudes towards tourism growth.

The study results also provide several recommendations for tourism planners and the Visit Greenville DMO as they plan for effective tourism growth. First, since the economic impact was the most significant predictor of residents' attitudes towards tourism growth, tourism planners need to collaborate with the government and private business owners to maintain, or increase, the economic benefits that the local community and residents receive while at the same time implementing measures to control sociocultural and environmental impacts. For example, the entities might consider turning unused spaces into event venues that will generate job opportunities and bring additional money into the community. In addition, residents will gain access to these places where they can enjoy socializing and leisure activities, eventually improving their standard of living.

Also, the study found that downtown residents are more favorable toward tourism growth than county residents. Therefore, tourism marketers are advised to take measures to improve county residents' attitudes to tourism growth while at the same time maintaining favorable attitudes from downtown residents. Specifically, tourism practitioners need to keep county residents up to date regarding the changes in Greenville by inviting locals and community leaders in the county to participate in the decision-making processes. Furthermore, the city government needs to promote the purchase of agricultural products produced in the county by downtown businesses (i.e., restaurants, bars, and caterers). Moreover, tourism practitioners need to plan major events, restaurant weeks, and farmer markets during the peak tourist season when county businesses and farmers can participate. Thus, county residents will perceive that they benefit from downtown tourism even though they are geographically distant from this area.

Moreover, age and gender moderated the effect of proximity to a tourism center on residents' attitudes towards tourism growth. For downtown residents and city residents, people who were above 40 were more favorable towards tourism growth. Thus, tourism planners need to concentrate on tourism business development (i.e., turning unused public spaces into events, organizing community events) so that middle-aged and other adults maintained their favorable attitudes towards tourism growth. For younger age groups, tourism planners can use hashtags on popular social media platforms to advertise events the communities are organizing and changes they are going through. In addition, for downtown residents, male residents were more favorable towards tourism growth. Regarding gender differences, male residents were more favorable towards tourism growth in the downtown area. On the contrary, for city residents, female residents were more favorable towards tourism growth. Hence, tourism practitioners can focus on tourism business development and community life enhancement so that both male and female residents are in favor of tourism growth in the downtown and city areas. However, the study indicated that length of residence didn't moderate the effect of proximity to a tourism center on residents' attitudes towards tourism growth. Destination management organizations and the local government need to control tourist flow in Greenville so that the development phase can be extended. Hence, long-term residents and short-term residents can have fewer negative attitudes towards tourism growth in Greenville.

\subsection{Limitations and Future Directions}

As with all research, this study has several limitations. First, it was conducted in downtown Greenville, a tourist zone. Due to the nature of the survey location, researchers may have surveyed more residents favorable towards tourism growth in this area. In 
other words, researchers did not survey in neighborhoods where residents might be less favorable towards tourism growth. Future studies might consider surveying additional neighborhoods, in areas outside of downtown, to balance residents' attitudes towards tourism growth. Secondly, this study included more city and county residents than downtown residents, meaning the results for perceived tourism impacts and their attitudes towards tourism growth may be skewed toward these populations. Future studies could collect responses based on similar sample sizes of downtown, city, and county residents.

Author Contributions: Y.A.: conceptualization, methodology, data curation, formal analysis, writing the original draft, revising the manuscript; J.-W.M.: methodology, data curation aid, formal analysis, writing the original draft and revising the manuscript; W.C.N.: project administration and resources. All authors have read and agreed to the published version of the manuscript.

Funding: This paper received the open access publishing fund offered by the Clemson University Library.

Institutional Review Board Statement: The study was conducted according to the guidelines of the Declaration of Helsinki, and approved by the Institutional Review Board of Clemson University (Protocal number:IRB 2015-362).

Informed Consent Statement: Informed consent was obtained from all subjects involved in the study.

Data Availability Statement: The data presented in this study are available on request from the corresponding author.

Conflicts of Interest: These authors declare no conflict of interest.

\section{References}

1. Choi, H.C.; Sirakaya, E. Sustainability indicators for managing community tourism. Tour. Manag. 2006, 27, 1274-1289. [CrossRef]

2. Lankford, S.V.; Howard, D.R. Developing a tourism impact attitude scale. Ann. Tour. Res. 1994, 21, 121-139. [CrossRef]

3. McIntyre, G. Sustainable Tourism Development: Guide for Local Planners; World Tourism Organization (WTO): Madrid, Spain, 1993.

4. Lee, T.H. Influence analysis of community resident support for sustainable tourism development. Tour. Manag. 2013, 34, 37-46. [CrossRef]

5. Choi, H.C.; Murray, I. Resident attitudes toward sustainable community tourism. J. Sustain. Tour. 2010, 18, 575-594. [CrossRef]

6. Gursoy, D.; Kendall, K.W. Hosting mega events. Ann. Tour. Res. 2006, 33, 603-623. [CrossRef]

7. Gursoy, D.; Jurowski, C.; Uysal, M. Resident attitudes: A Structural Modeling Approach. Ann. Tour. Res. 2002, 29, 79-105. [CrossRef]

8. Stylidis, D.; Biran, A.; Sit, J.; Szivas, E.M. Residents' support for tourism development: The role of residents' place image and perceived tourism impacts. Tour. Manag. 2014, 45, 260-274. [CrossRef]

9. Andereck, K.L.; Valentine, K.M.; Knopf, R.C.; Vogt, C.A. Residents' perceptions of community tourism impacts. Ann. Tour. Res. 2005, 32, 1056-1076. [CrossRef]

10. Deery, M.; Jago, L.; Fredline, L. Rethinking social impacts of tourism research: A new research agenda. Tour. Manag. 2012, 33, 64-73. [CrossRef]

11. Sinclair-Maragh, G.; Gursoy, D. A Conceptual Model of Residents' Support for Tourism Development in Developing Countries. Tour. Plan. Dev. 2016, 13, 1-22. [CrossRef]

12. Akis, S.; Peristianis, N.; Warner, J. Residents' attitudes to tourism development: The case of Cyprus. Tour. Manag. 1996, 17, 481-494. [CrossRef]

13. Nunkoo, R.; Gursoy, D. Residents' support for tourism: An Identity Perspective. Ann. Tour. Res. 2012, 39, 243-268. [CrossRef]

14. Ashworth, G.; Page, S. Urban tourism research: Recent progress and current paradoxes. Tour. Manag. 2011, 32, 1-15. [CrossRef]

15. Dirksmeier, P.; Helbrecht, I. Resident Perceptions of New Urban Tourism: A Neglected Geography of Prejudice. Geogr. Compass 2015, 9, 276-285. [CrossRef]

16. Khoshkam, M.; Marzuki, A.; Al-Mulali, U. Socio-demographic effects on Anzali wetland tourism development. Tour. Manag. 2016, 54, 96-106. [CrossRef]

17. Liu, X.; Li, J. Host Perceptions of Tourism Impact and Stage of Destination Development in a Developing Country. Sustainability 2018, 10, 2300. [CrossRef]

18. Sinclair-Maragh, G. Demographic analysis of residents' support for tourism development in Jamaica. J. Destin. Mark. Manag. 2017, 6, 5-12. [CrossRef]

19. Stets, J.E.; Biga, C.F. Bringing Identity Theory into Environmental Sociology. Sociol. Theory 2003, 21, 398-423. [CrossRef]

20. Lopez, F.; Mercader, S. Perceived Impacts of Tourism by the Resident Population in Torrevieja: National vs. Non-National Residents. Eur. J. Tour. Res. 2015, 10, 120-126. 
21. Travel Impact Analysis. The Economic Impact of Travel on South Carolina State and Counties. 2020. Available online: https:/ / embed.widencdn.net/pdf/plus/scprt/1zkpxfpdh4/2020EIReport_SC_Final.pdf?u=sgt8lu (accessed on 19 July 2021).

22. City of Greenville. Downtown Reborn. Available online: https://citygis.greenvillesc.gov/downtownreborn/index.html (accessed on 19 July 2021).

23. Visit Greenville SC. Signature Events. Available online: https://www.visitgreenvillesc.com/events/signature-events/ (accessed on 19 July 2021).

24. Eagly, A.H.; Chaiken, S. The Psychology of Attitudes; Harcourt Brace Jovanovich College Publishers: Fort Worth, TX, USA, 1993; ISBN 978-01-5500-097-1.

25. Zhang, Y.; Cole, S.T.; Chancellor, C.H. Facilitation of the SUS-TAS Application with Parsimony, Predictive Validity, and Global Interpretation Examination. J. Travel Res. 2014, 54, 744-757. [CrossRef]

26. Hadinejad, A.; Moyle, B.; Scott, N.; Kralj, A.; Nunkoo, R. Residents' attitudes to tourism: A review. Tour. Rev. 2019, 74, 150-165. [CrossRef]

27. Emerson, R.M. Social exchange theory. In Social Psychology: Sociological Perspectives; Rosenberg, M., Turner, R.H., Eds.; Basic Book: New York, NY, USA, 1981; pp. 30-65, ISBN 978-088-738-854-5.

28. Ap, J. Residents' perceptions on tourism impacts. Ann. Tour. Res. 1992, 19, 665-690. [CrossRef]

29. Cook, K.S.; Molm, L.D.; Yamagishi, T. Exchange Relations and Exchange Networks: Recent Developments in Social Ex-change Theory. In Theoretical Research Programs: Studies in the Growth of Theory; Berger, J., Zelditch, M., Eds.; Stanford University Press: Stanford, CA, USA, 1993; pp. 296-322, ISBN 978-080-472-230-8.

30. Emerson, R.M. Power-Dependence Relations. Am. Sociol. Rev. 1962, 27, 31. [CrossRef]

31. Yutyunyong, T.; Scott, N. The Integration of Social Exchange Theory and Social Representations Theory: A New Perspective on Residents' Perception Research. In CAUTHE 2009: See Change: Tourism \& Hospitality in a Dynamic World; Carlsen, J., Hughes, M., Holmes, K., Jones, R., Eds.; Curtin University of Technology: Fremental, Australia, 2009; pp. 549-568.

32. Homans, G. Social Behavior: Its Elementary Forms; Harcourt, Brace \& World: New York, NY, USA, 1961; ISBN 978-015-581-417-2.

33. Özel, Ç.H.; Kozak, N. An exploratory study of resident perceptions toward the tourism industry in Cappadocia: A Social Exchange Theory approach. Asia Pac. J. Tour. Res. 2017, 22, 284-300. [CrossRef]

34. Homans, G.C. Social Behavior as Exchange. Am. J. Sociol. 1958, 63, 597-606. [CrossRef]

35. Andriotis, K.; Vaughan, R.D. Urban Residents' Attitudes toward Tourism Development: The Case of Crete. J. Travel Res. 2003, 42, 172-185. [CrossRef]

36. Choi, H.-S.C.; Sirakaya, E. Measuring Residents' Attitude toward Sustainable Tourism: Development of Sustainable Tourism Attitude Scale. J. Travel Res. 2005, 43, 380-394. [CrossRef]

37. Tetsu, K. Tourism Promotion and Regional Development in Low-Income Developing Countries on JSTOR. Pak. Dev. Rev. 2006, 45, 417-424. [CrossRef]

38. García, F.A.; Vázquez, A.B.; Macías, R.C. Resident's attitudes towards the impacts of tourism. Tour. Manag. Perspect. 2015, 13, 33-40. [CrossRef]

39. Andereck, K.L.; Nyaupane, G. Exploring the Nature of Tourism and Quality of Life Perceptions among Residents. J. Travel Res. 2011, 50, 248-260. [CrossRef]

40. Liu, J.C.; Var, T. Resident attitudes toward tourism impacts in Hawaii. Ann. Tour. Res. 1986, 13, 193-214. [CrossRef]

41. Luo, X.; Bao, J. Exploring the impacts of tourism on the livelihoods of local poor: The role of local government and major investors. J. Sustain. Tour. 2019, 27, 344-359. [CrossRef]

42. Gursoy, D.; Chi, C.G.; Dyer, P. Locals' Attitudes toward Mass and Alternative Tourism: The Case of Sunshine Coast, Australia. J. Travel Res. 2009, 49, 381-394. [CrossRef]

43. Gursoy, D.; Rutherford, D.G. Host attitudes toward tourism: An Improved Structural Model. Ann. Tour. Res. 2004, 31, 495-516. [CrossRef]

44. Campón-Cerro, A.M.; Folgado-Fernández, J.A.; Hernández-Mogollón, J.M. Rural Destination Development Based on Olive Oil Tourism: The Impact of Residents' Community Attachment and Quality of Life on Their Support for Tourism Development. Sustainability 2017, 9, 1624. [CrossRef]

45. Glasson, J.; Godfrey, K.; Goodey, B. Towards Visitor Impact Management: Visitor Impacts, Carrying Capacity, and Management Responses in Europe's Historic Towns and Cities; Avebury: Aldershot, UK, 1995; ISBN 9781859720547.

46. Dyer, P.; Gursoy, D.; Sharma, B.; Carter, J. Structural modeling of resident perceptions of tourism and associated development on the Sunshine Coast, Australia. Tour. Manag. 2007, 28, 409-422. [CrossRef]

47. Yoon, Y.; Gursoy, D.; Chen, J. Validating a tourism development theory with structural equation modeling. Tour. Manag. 2001, 22, 363-372. [CrossRef]

48. Nunkoo, R.; Ramkissoon, H. Power, trust, social exchange and community support. Ann. Tour. Res. 2012, 39, 997-1023. [CrossRef]

49. Luo, S.; Furuya, K.; Xie, J. Impacts and residents' attitudes to flower-viewing tourism in Chengdu, PR China. Tour. Recreat. Res. 2020, 1-15. [CrossRef]

50. Meimand, S.E.; Khalifah, Z.; Zavadskas, E.K.; Mardani, A.; Najafipour, A.A.; Ahmad, U.N.U. Residents' Attitude toward Tourism Development: A Sociocultural Perspective. Sustainability 2017, 9, 1170. [CrossRef]

51. Bestard, A.B.; Nadal, J.R. Modelling environmental attitudes toward tourism. Tour. Manag. 2007, 28, 688-695. [CrossRef] 
52. Oviedo-Garcia, M.A.; Castellanos-Verdugo, M.; Martin-Ruiz, D. Gaining residents' support for tourism and planning. Int. J. Tour. Res. 2008, 10, 95-109. [CrossRef]

53. Rasoolimanesh, S.M.; Ringle, C.M.; Jaafar, M.; Ramayah, T. Urban vs. rural destinations: Residents' perceptions, community participation and support for tourism development. Tour. Manag. 2017, 60, 147-158. [CrossRef]

54. Gursoy, D.; Ouyang, Z.; Nunkoo, R.; Wei, W. Residents' impact perceptions of and attitudes towards tourism development: A meta-analysis. J. Hosp. Mark. Manag. 2019, 28, 306-333. [CrossRef]

55. Amuquandoh, F.E. Residents' perceptions of the environmental impacts of tourism in the Lake Bosomtwe Basin, Ghana. J. Sustain. Tour. 2010, 18, 223-238. [CrossRef]

56. Jeuring, J.H.G. Pluralising touristic production and consumption roles of residents? An SME perspective on proximity tourism Tour. Recreat. Res. 2018, 43, 147-160. [CrossRef]

57. Ashworth, G. Urban Tourism: Still an Imbalance in Attention? In Classic Reviews in Tourism; Cooper, C., Ed.; Channel View Publications: New York, NY, USA, 2003; pp. 143-163. [CrossRef]

58. Rasoolimanesh, S.M.; Taheri, B.; Gannon, M.J.; Vafaei-Zadeh, A.; Hanifah, H. Does living in the vicinity of heritage tourism sites influence residents' perceptions and attitudes? J. Sustain. Tour. 2019, 27, 1295-1317. [CrossRef]

59. Jurowski, C.; Gursoy, D. Distance effects on residents' attitudes toward tourism. Ann. Tour. Res. 2004, 31, 296-312. [CrossRef]

60. Weaver, D.B.; Lawton, L.J. Resident Perceptions in the Urban-Rural Fringe. Ann. Tour. Res. 2001, 28, 439-458. [CrossRef]

61. Sharpley, R. Host perceptions of tourism: A review of the research. Tour. Manag. 2014, 42, 37-49. [CrossRef]

62. Látková, P.; Vogt, C.A. Residents' Attitudes toward Existing and Future Tourism Development in Rural Communities. J. Travel Res. 2011, 51, 50-67. [CrossRef]

63. Rasoolimanesh, S.M.; Jaafar, M.; Kock, N.; Ramayah, T. A revised framework of social exchange theory to investigate the factors influencing residents' perceptions. Tour. Manag. Perspect. 2015, 16, 335-345. [CrossRef]

64. Tomljenovic, R.; Faulkner, B. Tourism and older residents in a sunbelt resort. Ann. Tour. Res. 2000, 27, 93-114. [CrossRef]

65. Orth, U.; Robins, R.W.; Widaman, K.F. Life-span development of self-esteem and its effects on important life outcomes. J. Pers. Soc. Psychol. 2012, 102, 1271-1288. [CrossRef] [PubMed]

66. Keogh, B. Resident Recreationists' Perceptions and Attitudes with Respect to Tourism Development. J. Appl. Recreat. Res. 1990, $15,71-83$.

67. Harrill, R.; Potts, T.D. Tourism Planning in Historic Districts: Attitudes Toward Tourism Development in Charleston. J. Am. Plan. Assoc. 2003, 69, 233-244. [CrossRef]

68. Mason, P.; Cheyne, J. Residents' attitudes to proposed tourism development. Ann. Tour. Res. 2000, 27, 391-411. [CrossRef]

69. Spence, J.T.; Helmreich, R.L. Masculinity E Femininity: Their Psychological Dimensions, Correlates, and Antecedents; University of Texas Press: Austin, TX, USA, 1978.

70. Wang, S. Predicting Effects of Demographics and Moderating Power of Engagement on Residents' Perceptions of Tourism Development. Eur. J. Tour. Res. 2013, 6, 170-182.

71. McGehee, N.G.; Andereck, K.L. Factors Predicting Rural Residents' Support of Tourism. J. Travel Res. 2004, 43, 131-140. [CrossRef]

72. Sharma, B.; Gursoy, D. An Examination of Changes in Residents' Perceptions of Tourism Impacts Over Time: The Impact of Residents' Socio-demographic Characteristics. Asia Pac. J. Tour. Res. 2015, 20, 1332-1352. [CrossRef]

73. Fortin, N.M. Gender Role Attitudes and the Labour-market Outcomes of Women across OECD Countries. Oxf. Rev. Econ. Policy 2005, 21, 416-438. [CrossRef]

74. Heilman, M.E. Description and Prescription: How Gender Stereotypes Prevent Women's Ascent Up the Organizational Ladder. J. Soc. Issues 2001, 57, 657-674. [CrossRef]

75. Almeida-García, F.; Fernández, M.; Ángeles, P.; Balbuena-Vázquez, A.; Macías, R.C. Residents' perceptions of tourism development in Benalmádena (Spain). Tour. Manag. 2016, 54, 259-274. [CrossRef]

76. Jurowski, C.; Uysal, M.; Williams, D.R. A Theoretical Analysis of Host Community Resident Reactions to Tourism. J. Travel Res. 1997, 36, 3-11. [CrossRef]

77. Wang, Y.; Pfister, R.E. Residents' Attitudes Toward Tourism and Perceived Personal Benefits in a Rural Community. J. Travel Res. 2008, 47, 84-93. [CrossRef]

78. Xu, S.; Barbieri, C.; Anderson, D.; Leung, Y.-F.; Rozier-Rich, S. Residents' perceptions of wine tourism development. Tour. Manag. 2016, 55, 276-286. [CrossRef]

79. Visit Greenville SC. All about Greenville, South Carolina. Available online: https://www.visitgreenvillesc.com/about-greenville/ (accessed on 20 July 2021).

80. Livability. 2016 Top 10 Downtowns. Available online: https://livability.com/top-10/downtowns/top-10-downtowns/2016 (accessed on 20 July 2021).

81. Rogers, L. 19 Cities That Must Be Seen in 2019. Available online: https:/ /viewfinder.expedia.com/cities-that-must-be-seen-this-year/ (accessed on 20 July 2021).

82. Visit Greenville SC. The Impact of Tourism in Greenville, SC. Available online: https:/ /assets.simpleviewinc.com/simpleview / image/upload/v1/clients /greenville/VGSC_FINAL_PurposeBook_6_18_20_fa87afba-6880-43a9-88d3-6b238ec5a1f3.pdf (accessed on 20 July 2021).

83. Yu, C.-P.; Chancellor, H.C.; Cole, S.T. Measuring Residents' Attitudes toward Sustainable Tourism: A Reexamination of the Sustainable Tourism Attitude Scale. J. Travel Res. 2009, 50, 57-63. [CrossRef] 
84. Nugroho, P.; Numata, S. Changes in residents' attitudes toward community-based tourism through destination development in Gunung Ciremai national park, Indonesia. Tour. Recreat. Res. 2020, 1-19. [CrossRef]

85. Tournois, L.; Djeric, G. Evaluating urban residents' attitudes towards tourism development in Belgrade (Serbia). Curr. Issues Tour. 2017, 22, 1670-1678. [CrossRef]

86. Butler, R. The concept of a tourist area cycle of evolution: Implications for management of resources. Can. Geogr. 1980, 24, 5-12. [CrossRef]

87. Sinclair-Maragh, G.; Gursoy, D.; Vieregge, M. Residents' perceptions toward tourism development: A factor-cluster approach. J. Destin. Mark. Manag. 2015, 4, 36-45. [CrossRef]

88. Miech, R.A.; Eaton, W.; Liang, K.-Y. Occupational Stratification Over the Life Course: A Comparison of Occupational Trajectories Across Race and Gender during the 1980s and 1990s. Work. Occup. 2003, 30, 440-473. [CrossRef]

89. Doxey, G.V. A Causation Theory of Visitor/Resident Irritants: Methodology and Research Inferences. In Proceedings of the Travel Research Association 6th Annual Conference, San Diego, CA, USA, 8-11 September 1975; pp. 195-198. 